\title{
Rozumieć przestrzeń O Miejscu Andrzeja Stasiuka
}

\begin{abstract}
Understanding the space
About Miejsce by Andrzej Stasiuk

Summary: The author attempts to interpret Andrzej Stasiuk's short story Miejsce, which was included in the new core curriculum of Polish language teaching in secondary schools. The aim of the article is to demonstrate that the theme of the place inscribed in Stasiuk's work can be perfectly described thanks to the adoption of a hermeneutical mode of reading, which will not only emphasize the importance of the phenomenology of space inscribed in the interpreted text, but will also show young readers how Heidegger's being in the place translates into building one's own identity.
\end{abstract}

Keywords: imaginative geography, memory, place, hermeneutics

Na liście lektur obowiązkowych znajdującej się w nowej podstawie programowej dla szkół ponadpodstawowych, która jest realizowana w roku szkolnym 2019/2020, znalazło się opowiadanie Andrzeja Stasiuka pt. Miejsce z tomu Opowieści galicyjskie ${ }^{1}$ wydanego w 1995 roku. Czy Stasiuk stanie się gwiazdą szkolnej listy lektur? Czy czeka go raczej los pisarza, którego choć przed interpretacyjną rutyną bronić przez jakiś czas będzie zasada świeżości obowiązująca w spotkaniu z nowym i nieznanym, to w końcu uda się go unieruchomić w szkolnych procedurach czytania proponujących lekturę ,techniczną”, obwarowaną łatwymi do przewidzenia problemami niejako przyległymi do „licealnego" czytania Stasiuka?

${ }^{1}$ https://archiwum.men.gov.pl/wp-content/uploads/2018/01/zalacznik-nr-1.pdf [data dostępu: 10.12.2018]. 


\section{Z „gębą” metafizyka w rękach}

Pomimo że w jeszcze obowiązującej podstawie programowej dla trzyletniego liceum ogólnokształcącego prozy Stasiuka zabrakło ${ }^{2}$, to twórczość autora Opowieści galicyjskich była jednak obecna w szkolnych podręcznikach. Przykładem wpisania Stasiuka w licealną narrację polonistyczną jest podręcznik Wydawnictwa Stentor promujący opowiadanie Babka ze wspomnianego już tomu z 1995 roku. Autor podręcznika Przeszłość to dziś proponuje lekturę opowiadania w klasie I. Tekst Stasiuka wpisany w rozdział zatytułowany Estetyka brzydoty ma, według Krzysztofa Mrowcewicza, prowokować dialog między współczesnością i barokiem. Nietrudno odgadnąć kierunki interpretacji opowiadania Babka, skoro umieszczono je w sąsiedztwie tak kanonicznych wierszy, jak Czyści i Piersi królowej utoczone z drewna Stanisława Grochowiaka, Rozprawa o stolikowych baranach, Szare eminencje zachwytu, Podłogo, błogosław! Mirona Białoszewskiego, Na imieniny i Koniec poezji Rafała Wojaczka, oraz tych, które szkolny kanon dopiero oswajają, ale czynią to z powodzeniem: Nie dam tytułu i Pieśni profana Marcina Świetlickiego3. Wybór ikonografii w pracach Władysława Hasiora czy Jerzego Dudy-Gracza oraz sąsiedztwo wymienionych wcześniej tekstów potwierdzają nie tylko bezapelacyjną przynależność Stasiuka do literackiej postturpistycznej awangardy estetycznej, ale również jego związki z kontestatorami i kaskaderami ${ }^{4}$ współczesnej kultury.

Jakby uzasadnień było mało, autor podręcznika sięga do Parnasu bis..., aby zacytować fragment noty biograficznej Stasiuka. Chwyt jest obliczony na wywołanie konkretnego efektu — biografia pisarza z Wołowca ma w jakimś sensie przypominać życiorysy poetów przeklętych (poètes maudits). Czytamy zatem:

Andrzej Stasiuk — „Brutalny prozaik i liryczny poeta” — jak określili go autorzy Parnasu bis [...]. Urodzony w Warszawie, porzucił miasto dla samotnej wiejskiej chałupy, pozbawionej nawet prądu. Autor kilku tomików

${ }^{2}$ Zob. Rozporzadzenie MEN z dnia 27 sierpnia 2012 r.w sprawie podstawy programowej wychowania przedszkolnego oraz kształcenia ogólnego w poszczególnych typach szkót. https:// www.terazmatura.pl/docs/Podstawa-programowa-z-jezyka-polskiego-szkola-ponadgimnazjalna. pdf [data dostępu: 10.12.2018].

${ }^{3}$ Zob. K. Mrowcewicz: Przeszłość to dziś. Literatura. Język. Kultura. I klasa liceum i technikum. Cz. 2. Warszawa 2002, s. 152-162.

${ }^{4}$ Nawiązuję do tytułu popularnej książki, z której w latach dziewięćdziesiątych ubiegłego wieku chętnie korzystali poloniści, rekompensując uczniom nieobecność poetów przeklętych w obowiązujących podręcznikach. Zob. Kaskaderzy literatury. O twórczości i legendzie Andrzeja Bursy, Marka Hłaski, Haliny Poświatowskiej, Edwarda Stachury, Ryszarda Milczewskiego-Bruna, Rafała Wojaczka. Red. E. Kolbus. Słowo wstępne J.Z. Brudnicki. Posłowie J. Marx. Łódź 1986. 
opowiadań oraz powieści, w których balladowy liryzm miesza się z brutalnością opisów i wulgarnością języka ${ }^{5}$.

Wystarczy sięgnąć do cytowanego słownika, aby dowiedzieć się z wyliczonych po przecinkach form życiowej aktywności Stasiuka, że uchodzi on za jednego ,z nielicznych polskich pisarzy z czadowym życiorysem”. Oprócz niebanalnej biografii pisarz może się pochwalić bogatym dorobkiem literackim, w którym Opowieści galicyjskie uchodzą — według autorów leksykonu — za najbardziej docenianą i najmniej kontrowersyjną książkę pisarza przeklętego:

Pozornie poszczególne opowieści robią wrażenie, że intencją autora było odmalowanie obrazu wsi galicyjskiej początku lat 90. XX wieku, [obrazu - M.W.D.] uchwyconego w momencie przemian społeczno-ekonomicznych ginącej cywilizacji PGR-ów [...]. Jednak końcowe opowiadania przekonują, że książka w rzeczywistości należy gatunkowo raczej do powieści, a to za sprawą splatania się w niej losów poszczególnych bohaterów wcześniejszych miniatur. Ku zaskoczeniu czytelnika głównym wymiarem utworu okazuje się nie realizm, lecz metafizyka ${ }^{6}$.

Wydaje się, że lekturze Babki w podręczniku Przeszłość to dziś towarzyszy ów metafizyczny paradygmat interpretacyjny. W zasadzie wszystkie polecenia dotyczące tego tekstu, począwszy od zadań związanych z dekompozycją fabuły, przez refleksję nad funkcją opisu świata babki, ustosunkowanie się do twierdzenia anonimowego krytyka, że opowiadanie skłania się ku metafizyce, odpowiedź na pytanie, czy jego autor jest nostalgikiem, aż po interpretację ostatniego zdania ${ }^{7}$, mają doprowadzić do uprawomocnienia tezy o prymacie metafizyki nad realizmem w pisarstwie Stasiuka. Czy trzeba Gombrowicza, aby wyobrazić sobie Stasiuka z ,gębą” metafizyka w rękach?

Można cynicznie stwierdzić, że oprócz metafizyki jest wiele innych powodów, by uznać, że Stasiuk miał ogromne szanse stać się ulubieńcem szkolnej listy lektur i zdobyć koszulkę lidera ${ }^{8}$. Warto wymienić przynajmniej dwa. Jest autorem opowiadań, a więc form krótkich, niezwykle „użytecznych” w szkolnej rzeczywistości. Miniaturowość tych narracji skutecznie zmniejsza ryzyko nieprzeczytania tekstu, a nawet jeśli i się to zdarzy, utwór zawsze można przeczy-

${ }^{5}$ K. Mrowcewicz: Przeszłość to dziś..., s. 157.

${ }^{6}$ P. Dunin-Wąsowicz, K. Varga: Parnas bis. Stownik literatury polskiej urodzonej po 1960 roku. Warszawa 1998, s. 200-201.

7 Zob. K. Mrowcewicz: Przeszłość to dziś..., s. 162.

${ }^{8}$ O koszulce lidera dla Stasiuka i Tokarczuk jako pisarzy urodzonych po 1960 roku, ale nadających ton prozie lat dziewięćdziesiątych pisał Dariusz Nowacki. Zob. D. Nowacki: Dwanaście groszy. Wokót prozy polskiej lat dziewięćdziesiątych. W: Idem: Zawód: czytelnik. Notatki o prozie polskiej lat 90. Kraków 1999, s. 18-19. 
tać podczas lekcji. Opowiadania Stasiuka są ponadto „polonistycznie” wdzięczne, bo niestety z łatwością poddają się rozmaitym trybom lektury, co czyni z nich nierzadko poligon przedmaturalnych powtórek wątków, toposów, motywów, problemów... Przywołane opowiadanie Babka znakomicie „sprawdza się” choćby w kontekście problematyki związanej z małymi ojczyznami, mityzacją rzeczywistości, feminizmem, metafizyką, postromantyczną wrażliwością galicyjskiego „ludu”, opozycją: ja — wspólnota, tożsamością, wykorzenieniem czy z kondycją outsidera9 ${ }^{9}$ Mam wrażenie, że twórcy nowej podstawy programowej, mając świadomość nie tylko doniosłości prozy Stasiuka, lecz także szkolnej koniunktury, dostrzegli w obecności jego tekstów na lekcjach polskiego nie tylko szansę na spotkanie ze znakomitą współczesną prozą, ale też możliwość realizacji istotnych polonistycznych lejtmotywów.

\section{Sądź książkę po okładce}

Uznając Opowieści galicyjskie za „niewyczerpane źródło” takich motywów, warto nie tracić z pola widzenia okładek kolejnych edycji tomu, które można potraktować z jednej strony jako pretekst do rozmowy o przeczuciach (hermeneutycznych przedsądach) na temat książki, a z drugiej — jako interesujące ćwiczenie z zakresu interpretacji tekstów kultury. Warto więc na lekcji zaproponować uczniom taki właśnie eksperyment, którego inspiracji należałoby zapewne szu-

${ }^{9}$ Warto choć wybiórczo przypomnieć pewne ustalenia wynikające ze studiów nad wczesną twórczością Stasiuka. Przemysław Czapliński w jego prozie, podobnie zresztą jak w twórczości Olgi Tokarczuk, dostrzegał zainteresowanie rzeczami pierwszymi, rozumianymi jako materia, z której wyziera egzystencjalny sens. W tym kontekście Stasiuk jest mistrzem opisu zwyczajności, która w niespodziewanej odsłonie staje się epifanią sensu. (Zob. P. Czapliński: Świat podrobiony. Krytyka i literatura wobec nowej rzeczywistości. Kraków 2003, s. 88-94). W przewodniku po współczesnej literaturze ten sam krytyk, ustalając topikę twórczości Stasiuka, dodaje do metafizyki słowo klucz - małe ojczyzny, ,mityczne obszary pojednania człowieka z historią, czasoprzestrzenie spełnione: [...] Beskid Niski”, których ,prezentacja w powieściach wykorzystujących konwencje prozy edukacyjnej pozwalała zaakcentować harmonijność procesu dojrzewania, a także osiągniętą dzięki intymnemu związkowi z własną przestrzenią zdolność współodczuwania z istnieniem i wyczulenie na metafizyczny aspekt bytu" (P. Czapliński, P. Śliwiński: Literatura polska 1976-1998. Przewodnik po prozie i poezji. Kraków 1999, s. 259-260), co z kolei prowadzi do swoistej fetyszyzacji pojęcia swojskości i wykorzenienia, odmienianych podczas lektury tekstów Stasiuka przez wszystkie przypadki. Zob. A. Jamrozek-S ow a: Powietrze petne duchów. W: Miejsca, ludzie, opowieści. O twórczości Andrzeja Stasiuka. Red. M. Rabizo-Birek, M. Zatorska, D. Niezgoda. Rzeszów 2018, s. 183-186. Por. E. Kledzik: Prowincjonalizowanie. Twórczość Jurija Brězana, Wolfganga Hilbiga i Andrzeja Stasiuka w perspektywie postkolonialnej. Poznań 2013. 
kać w koncepcji koła hermeneutycznego, wymuszającego niejako formułowanie przedsądów i konfrontowanie ich z narastającym materiałem interpretacyjnym, wynikającym z coraz uważniejszego (i świadomego) czytania tekstu.

Opowiadania drukowane początkowo na łamach „Tygodnika Powszechnego" doczekały się w 1995 roku edycji książkowej w Wydawnictwie Znak. Firmowała je okładka będąca metonimią ,polskiej duszy”. Fotografia samotnej wierzby poszarpanej przez wiatry i ogołoconej z liści nie tylko przywołuje typowo polskie, mazowieckie krajobrazy, rodzimą wrażliwość wyhodowaną na mazurkach Szopena, nostalgię, mityczne przywiązanie do ziemi, ale staje się również metaforą schyłku, jakiegoś nieuniknionego uskoku w czasie.

Kolejna okładka, tym razem już Wydawnictwa Czarne, zaprojektowana przez Kamila Targosza, podkreśla nadrealizm, a może właśnie metafizyczność opowiadań Stasiuka. Przedstawia ona nogi mężczyzny unoszącego się nad pokrytymi śniegiem polami. Ciemna kolorystyka każe przypisywać obrazowi konotacje funeralne. Opisywany świat zmierza ku końcowi, być może już się skończył, a Chagallowska estetyka nierealności jedynie wzmacnia tego rodzaju przekaz.

Kolejna propozycja okładki Kamila Targosza pochodzi z 2001 roku. Utrzymana w czerni i bieli, przedstawia profil afrykańskiej maski i stojącą na niej świnię. Nietrudno wyobrazić sobie dyskusję nad interpretacją takiego przekazu wyzyskującego symbolikę kosmogonicznego mitu, którego praźródłem są wierzenia będące fundamentem naturalnego porządku. Faktu, że reprezentantem owego porządku jest świnia, nie należy odczytywać ironicznie. Wręcz przeciwnie. Dziwaczna relacja między zwierzęciem a maską wydaje się nie tylko zapowiedzią szczególnej wrażliwości Stasiuka na obecność braci mniejszych ${ }^{10}$, ale przede wszystkim sygnałem korespondencji doczesności oraz widzialności z wiecznością i tym, co skryte. To właśnie zza prozaicznych, ale i paradoksalnie wzniosłych ${ }^{11}$ detali dnia codziennego wyziera ostateczny sens, o którym w kontekście twórczości Stasiuka wspomniał Przemysław Czapliński ${ }^{12}$.

Spośród okładek i kolorem, i symetrią zdecydowanie wyróżnia się ostatnie wydanie opowiadań. Ilustracja przedstawia linię horyzontu, miejsce zetknięcia się ziemi z niebem, przy czym ta pierwsza, zajmując większą część okładki, sprawia wrażenie, że wypycha niebo ku górze. Ono samo wydaje się zmniej-

${ }^{10}$ Szczególnie wyraźnie widać to w opowiadaniu Suka z tomu Grochów, choć przecież cała proza Stasiuka jest dla mnie przeczuciem powinowactwa losów ludzi i zwierząt. O wrażliwości na ten rodzaj współbytowania w świecie pisarz mówi w wywiadzie z Dorotą Wodecką. Zob. Życie to jednak strata jest. Andrzej Stasiuk w rozmowach z Dorota Wodecka. Warszawa 2015.

${ }^{11}$ Znakomicie wzniosłość opowiadań Stasiuka podkreślił D. Nowacki: ,[...] bohaterowie Stasiuka to wyniosłe emblematy, ikony przechowujące jakąś prawdę i świętość egzystencji, nie zaś figury wycięte z gorlickiej makatki, kukiełki wypożyczone z etnograficznego muzeum". D. Now acki: Raz lepiej, raz gorzej. W: Idem: Zawód: czytelnik..., s. 85.

12 Zob. P. Czapliński: Świat podrobiony... 
szane przez jakąś oddolną siłę. Ziemia jest popękana, a jej szczeliny przywodzą na myśl z jednej strony geologiczne uskoki czy koryta wód podziemnych, $z$ drugiej - zmarszczki lub poprzerywany krwiobieg, swoiste pismo. Jedno nie budzi wątpliwości. Ziemia jest nie tylko żywą materią, ale również przestrzenią, w której zakodowana jest pamięć. Tym samym wydaje się, że ta właśnie okładka jak żadna inna dowartościowuje kategorię miejsca, rozumianego jako przestrzeń pleniących się sensów. Wybór między ziemią — spękaną skałą a ziemią skontaminowaną z ludzkim krwiobiegiem sprawia, że interpretacja staje się przestrzenią negocjacji, tak jak rozumienie miejsca wynika z ciągłej z nim relacji i nieustannego uzgadniania znaczeń.

\section{Przestrzeń nie jest dana, lecz zadana}

Miejsce Stasiuka jest fantazmatyczną opowieścią o nieistniejącej już cerkwi. Pozostałości po świątyni każą snuć domysły na temat jej początków, wznoszących ją budowniczych, architektury oraz tłumów wiernych przybywających na nabożeństwa. Pusta przestrzeń, w jakiś sposób podobna do tej z Historii Krzysztofa Kamila Baczyńskiego, zmusza do kontemplacji miejsca. Praca myśli skutkuje wizją przeszłości. Jej obrazy są, według narratora opowiadania, konieczne, wypełniają wszak swą materią puste pola:

Giacomo Casanova dogorywat na zamku w Dux. 30 tysięcy dońskich Kozaków maszerowało na Indie. Ludwik XVI, niczego jeszcze nie podejrzewajac, konstruowat swoje ostatnie kłódki i zamki. Te wszystkie daty sa dokładnie ustalone, przestrzeń między nimi wypetniaja opisy, jeżeli pozostały jakieś szczeliny, to zasklepiono je przemyślnymi hipotezami albo poezja. Potrzeba porzadku, nazwy, skutku i przyczyny dotyczy również imaginacji. $Z$ tego biora się wszystkie zmyślone historie, $w$ które z czasem zaczynamy wierzycín ${ }^{13}$.

I tak, Stasiuk w Miejscu konstruuje terytorium w ramach geografii imaginacyjnej. Prawdopodobnie o taką właśnie konstrukcję przestrzeni mu chodzi, kiedy na pytanie o istotę geografii odpowiada, że składają się na nią medytacja nad przestrzenią oraz doświadczenie religijne ${ }^{14}$. Wydaje się, że terytorium w Miejscu powstaje z naturalnych praktyk opowiadania, jakie stosuje narrator. Doświadczając pustki po cerkwi, zaczyna tworzyć jej imaginacyjne obra-

\footnotetext{
${ }^{13}$ A. Stasiuk: Miejsce. W: Idem: Opowieści galicyjskie. Wołowiec 2001, s. 29-30.

${ }^{14}$ Zob. Życie to jednak strata jest..., s. 110.
} 
zy, uzgadniając ich kolejność oraz znaczenie. W wyobraźni odpamiętuje więc poszczególne etapy powstawania świątyni, korzystając nie tylko ze szczególnej wrażliwości na sygnały wysyłane przez przestrzeń, ale również z wiedzy o przeszłości. Narrator sytuuje zatem początek budowy cerkwi w zimie, kiedy mężczyźni zwolnieni z prac na roli mogli się zająć poszukiwaniem najlepszych drzew w lesie oraz ich wyrębem. Analogicznie finał budowy przypada na późną jesień - mityczne, koliste odczuwanie czasu powinno przecież zamykać rytm ludzkiej aktywności w czytelne cykle. Aby historia mocniej się ukonkretniła, narrator powołuje do istnienia dwóch silnych mężczyzn, czyniąc ich odpowiedzialnymi za wybór i zwiezienie drewna na miejsce budowy. Z kolei w celu uprawdopodobnienia owej historii korzysta $\mathrm{z}$ wiedzy zdobytej podczas rozmów ze starymi ludźmi, wspominającymi „niegdysiejsze śniegi”, w których konie zapadały się po brzuchy.

Rekonstrukcja przeszłości stanowi wypadkową imaginacji, doświadczenia pamięci ,,protetycznej”, zdobytej dzięki przekazowi innych, oraz wiedzy na temat sztuki sakralnej. Korzystając z jej zasobów, narrator w swej imaginacyjnej opowieści stawia poszczególne ściany, dbając o wschodnią orientację świątyni. Troska o jej poprawne usytuowanie nie jest wyrażona wprost, lecz jedynie w formie sugestii dotyczącej kierunku wpadania promieni zachodzącego słońca przez uchylone drzwi. Czytelnik jest świadkiem powstawania snycerki, umieszczania ikon Świętego Dymitra czy proroka Eliasza z lewej strony ikonostasu. Odtwarzanie przestrzeni wydaje się więc nie tylko zadaniem emocjonalnym, ale również intelektualnym ${ }^{15}$.

Niebagatelną rolę w opowieści narratora odgrywają świadkowie tamtych czasów, których relacje z jednej strony wypełniają białe plamy, a z drugiej każą konfrontować przeszłość z własną wrażliwością i potrzebami duchowymi. Tak jest w przypadku dziewięćdziesięcioletniego człowieka, który z pomocą swych bliskich udaje się prawdopodobnie w ostatnią podróż, aby zobaczyć to, co zostało z cerkwi, współtworzącej kiedyś pejzaż jego młodości:

Mój ojciec w 95 roku pomagat zmieniać tutaj dach. Gont przykryli blachą. A potem mnie tutaj ochrzcili.

Szedłem później obok wozu, a stary człowiek wskazywat miejsca, gdzie stały domy, wymieniat imiona, opowiadat okruchy jakichś zdarzeń. Jechat przez wieś, która istniała w jego pamięci. Ani czas, ani ogień, ani kruchość nie miaty do niej dostęp ${ }^{16}$.

${ }^{15}$ Narrator mimochodem wymienia poszczególne elementy nieistniejącej cerkwi, które choć przywoływane przez osobę spoza obrządku prawosławnego (krytycy niejednokrotnie podkreślali, że narrator jest przybyszem, obcym), nie są pozbawione sakralnego i kulturowego kontekstu niezbędnego do ich rozumienia. Zob. B. Uspienski: Krzyż i koło. Z historii symboliki chrześcijańskiej. Tłum. i przedmowa B. Żyłko. Gdańsk 2010.

${ }^{16}$ A. Stasiuk: Miejsce..., s. 34. 
Spotkanie z miejscem nie sprowadza się jedynie do odczuwania jego genius loci, ale oznacza przede wszystkim dialog z widmową przeszłością, która dzięki zaangażowaniu $\mathrm{w}$ jego budowanie nabiera realnych kształtów. Prawdopodobnie ów dialog nie byłby możliwy dzięki pamięci kulturowej rozumianej jako

charakterystyczny dla każdej społeczności i epoki zasób ponownie używanych tekstów, wyobrażeń, rytuałów, w którym pielęgnuje, stabilizuje i przekazuje ona wyobrażenie o samej sobie, dzieloną zbiorowo wiedzę przeważnie [...] o przeszłości, na której grupa opiera świadomość swojej jedności i swoistości ${ }^{17}$.

Stasiuk jednakże nie mówi o pamięci zbiorowej, odwrotnie - można odnieść wrażenie, że pamięć jest zawsze domeną jednostki, i to jednostka jest za nią odpowiedzialna. Ma rację Yi-Fu Tuan, pisząc, że ,przedmiot lub miejsce zyskuje konkretną realność, jeśli doświadczamy go w sposób totalny, to znaczy wszystkimi zmysłami oraz aktywną i refleksyjną myślą"18.

Takie doświadczenie jest udziałem narratora Miejsca. Zapewne tego rodzaju ogląd przestrzeni z racji swej zmienności, dynamiki oraz subiektywności będzie skutkować na lekcji języka polskiego projektem interpretacyjnym skupionym na takich hasłach, jak permanentna transgresja, życie w drodze czy (re)konstruowanie tożsamości. Zaproponowany namysł nad miejscem prowadzi jednakże do niezwykle istotnej dla edukacji polonistycznej refleksji nad kolejnością pytań:

[...] pytanie: kim jestem? winny poprzedzać pytania: skąd jestem? i gdzie jestem?, a więc kładące nacisk nie tyle na osiadłość, zakorzenienie, ile na mobilność, ale naznaczoną śladami miejsc kolejnych pobytów ${ }^{19}$.

Tak więc próba odpowiedzi na ontologiczne pytanie „kim jestem?” w kontekście fenomenologii miejsca musi wynikać z przemyślenia dwu innych pytań — „skąd jestem?” i „gdzie jestem?”. Namysł nad nimi umożliwia hermeneutyczna wędrówka śladami swych poprzednich pobytów. Innymi słowy, znajdując się tam, gdzie już kiedyś byliśmy, ale z nieco innym bagażem doświadczeń, inaczej niż wcześniej rozumiemy swe doświadczenie. I choć hermeneutyka rezygnuje z pytań o prawdę w kategoriach obiektywności, a sam Paul Ricoeur rozbija podmiot, twierdząc, że każdy akt jego konstruowania podaje w wątpliwość wcześniejszą jego konstrukcję, to jednocześnie obiecuje, że człowiek, ,zanurzając się" w kulturze i tym samym wędrując śladami innych, w jakimś stopniu

17 J. Assmann: Pamięć zbiorowa i tożsamość kulturowa. Tłum. S. Dyroff, R. Żytyniec. „Borussia” 2003, nr 29, s. 16.

18 Yi-Fu Tuan: Przestrzeń i miejsce. Tłum. A. Morawińska. Warszawa 1987, s. 31.

19 E. Rybicka: Geopoetyka. Przestrzeń i miejsce we wspótczesnych teoriach i praktykach literackich. Kraków 2014, s. 51. 
rozpozna się $\mathrm{w}$ ich opowieściach ${ }^{20}$. W tym kontekście należałoby więc mówić o narracyjności ludzkiego życia. Wspomina o niej, jako o terapeutycznej cesze życia, również Stasiuk:

Moje prywatne doświadczenie zamknięte jest w opowieści, która o dziwo bywa doświadczeniem całkiem powszechnym. Ostatnio napisał do mnie stary, dojrzały facet, że czytając moją książkę, słyszał w głowie własny głos. Przecież o nic więcej w tym pisaniu nie chodzi, jak tylko o chwilowe zawieszenie samotności istnienia ${ }^{21}$.

Narracyjność życia pomaga nie tylko odnaleźć drogę do siebie i Drugiego, ale otwiera również nową perspektywę myślenia o przestrzeni, którą Hanna Buczyńska-Garewicz nazywa hermeneutyką miejsc. Według filozofki wszak, są to „Miejsca [...] określane jakościowo, przez nawarstwione w nich treści duchowe, a nie ilościowo czy formalnie wobec innych miejsc" ${ }^{22}$. Dzięki swoistym „nawarstwieniom” narracyjnym taka przestrzeń staje się miejscem zamieszkanym i wpisuje się w duchową topografię świata człowieka. Może dlatego narrator Stasiuka, dowiadując się, że pozostałości po cerkwi mają być przeniesione do skansenu i tam zrekonstruowane, czyli niejako oddane miejscu pustemu, bez narracyjnych nawarstwień, wyznaje:

Nie jestem mitośnikiem ruin. Ale wizja odnowionej światyni stojącej pomiędzy innymi domami i sprzętami tak samo wyjętymi z ich czasu i miejsca ma w sobie skaze jednowymiarowości. [...] Lecz miejsca nie można przenieść. Miejsce nie ma wymiarów. Jest punktem i nieuchwytna przestrzenią. Dlatego wciaż nie mam pewności, czy rzeczywiście ja zabrano ${ }^{23}$.

To obiekt konstytuuje miejsce, bo istota miejsca nie jest dana, lecz zadana. Urzeczywistnia się w relacji człowieka z przestrzenią, dodajmy — relacji, którą można by za Heideggerem nazwać zamieszkiwaniem ${ }^{24}$. Hanna Buczyńska-Garewicz, interpretując Heideggerowskie pojęcie „okolica”, twierdzi, że jest nią coś, „,co znajduje się wokół człowieka, co konstytuuje się ze względu na niego, co dobrze znane i bliskie, wobec czego występuje związek zażyłości.

${ }^{20}$ Zob. P. Ricoeur: Egzystencja i hermeneutyka. Rozprawyo metodzie. Tłum. E. Bieńkowska. Wybór i oprac. S. Cichowicz. Warszawa 2003; P. Ricoeur: O sobie samym jako obcym. Tłum. B. Chełstowski. Oprac. M. Kowalska. Warszawa 2003.

${ }^{21} \dot{Z}$ ycie to jednak strata jest..., s. 176.

${ }^{22}$ H. Buczyńska-Garewicz: Miejsca, strony, okolice. Przyczynek do fenomenologii przestrzeni. Kraków 2006, s. 11.

${ }^{23}$ A. Stasiuk: Miejsce..., s. 35.

${ }^{24}$ Zob. M. Heidegger: „,...poetycko mieszka człowiek...”; Budować, mieszkać, myśleć. W: Idem: Odczyty i rozprawy. Tłum. J. Mizera. Kraków 2002. 
Okolicą są miejsca wyróżnione ze względu na bycie ludzkie"25. Przestrzeń jest zamieszkiwana wówczas, gdy człowiek zdobywa się na wędrówkę i pielgrzymowanie, które nie oznaczają jedynie ruchu fizycznego, lecz proces rozumienia treści miejsc. Tego rodzaju ruch ma więc hermeneutyczny wymiar, gdyż wyrastając $\mathrm{z}$ chęci zrozumienia siebie i swego domu, skłania do otwartości i nieustannego negocjowania znaczeń.

Nieprzypadkowo więc narrator Miejsca jest przybyszem, który jak większość bohaterów/narratorów prozy Stasiuka ma silne poczucie „ruchomości granic" ${ }^{26}$. Jedno z ostatnich zdań opowiadania ([Miejsce - M.W.D] Jest punktem i nieuchwytna przestrzeniq. Dlatego wciąz nie mam pewności, czy rzeczywiście ja zabrano ${ }^{27}$ ) jak żadne inne wyraża przekonanie, że człowiek ,zamieszkuje" dzięki rozumieniu miejsca ${ }^{28}$.

W opowiadaniu Stasiuka niebagatelną rolę oprócz narratora odgrywa turysta. Nie wiedzieć czemu, zawędrował do miejsca, w którym kiedyś stała cerkiew. Jego obecność przeszkadza narratorowi w imaginacyjnym odtwarzaniu obrazów przeszłości. Poezja ruin nie może się dopełnić, a rytuał spotkania imaginacji, nadto pamięci przerywają narratorowi zdawkowe, drażniące pytania młodego mężczyzny uzbrojonego w plecak, mapę i aparat fotograficzny. Wymienione przedmioty mają mu zapewnić efektywną i efektowną przygodę, gwarantują wszak bezpieczeństwo piechurowi, jego czasowi i pamięci. „Wyprawa” turysty nie jest nastawiona na poznanie, lecz jedynie na dowiedzenie się, jej celem nie jest przeżycie, lecz zdobycie oraz zagarnięcie. To nie hermeneutyczna wędrówka po sensach, lecz maraton uwieńczony nie narracją o miejscu, ale uwieczniony najwyżej kilkoma fotografiami - nędznymi erzacami pamięci, dokumentującymi pobieżne i fragmentaryczne doświadczenie. Wszystko, co mężczyzna robi, jest pospieszne (Chciat jeszcze coś pstryknać, ale stońce właśnie znikło ${ }^{29}$ ), nerwowe i przypadkowe (Pomyślatem, że mężczyzna, zapewne przez przypadek, sfotografowat przestrzeń, w której znajdowat się ikonostas $\left.{ }^{30}\right)$. Jego obecność jest irytująca:

— Co tu byto? - zapytat mnie mężczyzna. [...]

- Cerkiew - odpowiedziatem.

- I co sie stato?

- Nic. Zabrali do muzeum.

${ }^{25}$ H. Buczyńska-Garewicz: Miejsca, strony, okolice..., s. 27.

${ }^{26}$ E. Dutka: Nieoczywistość i wciąż nieoswojona przestrzeń - proza Andrzeja Stasiuka jako głos $w$ dyskusji na temat Europy Środkowej. W: 20 lat literatury polskiej 1989-2009. Cz. 2: Życie literackie po roku 1989. Red. D. Nowacki, K. Uniłowski. Katowice 2012, s. 163.

27 A. Stasiuk: Miejsce..., s. 35.

${ }^{28}$ Zob. H. Buczyńska-Garewicz: Miejsca, strony, okolice..., s. 44.

${ }^{29}$ A. Stasiuk: Miejsce..., s. 34.

${ }^{30}$ Ibidem, s. 31. 
- Cata?

- Cata, ale po kawatku.

Wszedt na udeptany placyk $i$ rozejrzat się wokót, jakby szukat ścian i sklepienia. Potem wynalazt stoneczna plame, obejmowata prezbiterium, i pstryknat praktica.

- Szkoda - powiedziat.

- Tak-odburknatem ${ }^{31}$.

Wydaje się, że nieznajomego dobrze mogłaby opisać kategoria Baumanowskiego ponowoczesnego turysty, dla którego miejsce postoju staje się jedynie obozowiskiem, a nie domem, gdyż nie chce ,zaciągać zobowiązań [wobec tubylców - M.W.D] na daleką metę i niczemu, co dziś się zdarza, nie dawać prawa do krępowania przyszłości. [...] Świat turysty składa się z widoków, a nie kształtów"32. Turysta, przybywając, stanowi epizod, który przecież nie staje się wątkiem większej opowieści i nie wpływa znacząco na jej rozwój. Odnoszę wrażenie, że narrator Miejsca w finale opowiadania prawdopodobnie bezskutecznie próbuje wyprowadzić mężczyznę ze stanu niezaangażowania, nierozumienia miejsca, niezamieszkiwania, a tym samym - egzystencjalnej bezdomności. Kiedy turysta zamyka w końcu futerał aparatu, ponieważ zapadający zmrok uniemożliwia mu robienie zdjęć, pyta o miejsce, gdzie kiedyś było wejście do cerkwi. Narrator odpowiada: Tu. Stoi pan na progu ${ }^{33}$.

Próg - symboliczne miejsce, w którym znajduje się turysta, nie jest, jak należy przypuszczać, wyłącznie kolejnym świadectwem słabości autora do miejsc granicznych ${ }^{34}$. Być może pozycja, jaką zajął turysta w odniesieniu do nierozumianego przez siebie miejsca, antycypuje przyjęcie przez niego innej perspektywy w oglądzie przestrzeni. Próg byłby więc zapowiedzią wędrówki, a tej niezbywalną korzyścią jest troska o miejsce, które przecież wciąż na nowo przez nas myślane, konstytuuje nasze jestestwo.

Dlaczego Miejsce Stasiuka miałoby być atrakcyjną propozycją na lekcjach języka polskiego? Według mnie, jest opowiadaniem na wskroś ,,pedagogicznym", przygotowuje do uczestnictwa we wspólnocie narracji oraz do gotowości włączania uczniów do niekończącego się procesu (re)konstruowania własnej tożsamości. Myślę, że hermeneutyczny namysł Stasiuka nad miejscem, prowadzący do rozumienia przestrzeni, a tym samym świadomego „zamieszkiwania”

${ }^{31}$ Ibidem, s. 29.

${ }^{32}$ Z. Bauman: O turystach i wtóczeggach, czyli o bohaterach i o ofiarach ponowoczesności. W: Idem: Ponowoczesność jako źródło cierpień. Warszawa 2000, s. 147.

33 A. Stasiuk: Miejsce..., 35.

${ }^{34}$ Zob. J. Lech: Z Dukli po Babadag. Uwagi o prozie podróżniczej Andrzeja Stasiuka. W: Miejsca, ludzie, opowieści..., s. 145-161. 
w niej człowieka, ma wiele wspólnego z edukacją. To edukacja, jak twierdzi Lech Witkowski, może

sprzyjać codziennemu odkrywaniu spłyceń w rozumieniu świata i zachęcać do przeciwstawienia się rezygnacji z wysiłku dostrzegania spłyceń, iluzji, wykorzenienia, wydziedziczenia z kultury jako niewyczerpanej skarbnicy myśli, sprzyjającej naszym zwielokrotnionym ponownym narodzinom duchowym, zwielokrotniającym nam duszę ${ }^{35}$.

Efektem takiej edukacji będzie troska o człowieka.

\section{Bibliografia}

Assmann J.: Pamięć zbiorowa i tożsamość kulturowa. Tłum. S. Dyroff, R. Żytyniec. „Borussia" 2003, nr 29.

Bauman Z.: O turystach i włóczęgach, czyli o bohaterach i o ofiarach ponowoczesności. W: Idem: Ponowoczesność jako źródlo cierpień. Warszawa 2000.

Buczyńska-Garewicz H.: Miejsca, strony, okolice. Przyczynek do fenomenologii przestrzeni. Kraków 2006.

Czapliński P.: Świat podrobiony. Krytyka i literatura wobec nowej rzeczywistości. Kraków 2003.

Czapliński P., Śliwiński P.: Literatura polska 1976-1998. Przewodnik po prozie i poezji. Kraków 1999.

Dunin-Wąsowicz P., Varga K.: Parnas bis. Stownik literatury polskiej urodzonej po 1960 roku. Warszawa 1998.

Dutka E.: Nieoczywistość i wciąż nieoswojona przestrzeń - proza Andrzeja Stasiuka jako głos w dyskusji na temat Europy Środkowej. W: 20 lat literatury polskiej 1989-2009. Cz. 2: Życie literackie po roku 1989. Red. D. Nowacki, K. Uniłowski. Katowice 2012.

Heidegger M.: Budować, mieszkać, myśleć. W: Idem: Odczyty i rozprawy. Tłum. J. Mizera. Kraków 2002.

Heidegger M.: , ,...poetycko mieszka człowiek...”. W: Idem: Odczyty i rozprawy. Tłum. J. Mizera. Kraków 2002.

Jamrozek-Sow a A.: Powietrze petne duchów. W: Miejsca, ludzie, opowieści. O twórczości Andrzeja Stasiuka. Red. M. Rabizo-Birek, M. Zatorska, D. Niezgoda. Rzeszów 2018.

Kaskaderzy literatury. O twórczości i legendzie Andrzeja Bursy, Marka Hłaski, Haliny Poświatowskiej, Edwarda Stachury, Ryszarda Milczewskiego-Bruna, Rafała Wojaczka. Red. E. Kolbus. Słowo wstępne J.Z. Brudnicki. Posłowie J. Marx. Łódź 1986.

Kledzik E.: Prowincjonalizowanie. Twórczość Jurija Brězana, Wolfganga Hilbiga i Andrzeja Stasiuka w perspektywie postkolonialnej. Poznań 2013.

Lech J.: Z Dukli po Babadag. Uwagi o prozie podróżniczej Andrzeja Stasiuka. W: Miejsca, ludzie, opowieści. O twórczości Andrzeja Stasiuka. Red. M. Rabizo-Birek, M. Zatorska, D. Niezgoda. Rzeszów 2018.

${ }^{35}$ L. Witkowski: Między pedagogika, filozofia i kulturą. Studia, eseje, szkice. Warszawa 2007, s. 278. 
Mrowcewicz K.: Przeszłość to dziś. Literatura. Język. Kultura. I klasa liceum i technikum. Cz. 2. Warszawa 2002.

Nowacki D.: Dwanaście groszy. Wokót prozy polskiej lat dziewięćdziesiątych. W: Idem: Zawód: czytelnik. Notatki o prozie polskiej lat 90. Kraków 1999.

Nowacki D.: Raz lepiej, raz gorzej. W: Idem: Zawód: czytelnik. Notatki o prozie polskiej lat 90. Kraków 1999.

Ricoeur P.: Egzystencja i hermeneutyka. Rozprawy o metodzie. Tłum. E. Bieńkowska. Wybór i oprac. S. Cichowicz. Warszawa 2003.

Ricoeur P.: O sobie samym jako obcym. Tłum. B. Chełstowski. Oprac. M. Kowalska. Warszawa 2003.

Rybicka E.: Geopoetyka. Przestrzeń i miejsce we wspótczesnych teoriach i praktykach literackich. Kraków 2014.

Stasiuk A.: Miejsce. W: Idem: Opowieści galicyjskie. Wołowiec 2001.

Tuan Yi-Fu: Przestrzeń i miejsce. Przeł. A. Morawińska. Warszawa 1987.

Uspienski B.: Krzyż i koło. Z historii symboliki chrześcijańskiej. Tłum. i przedmowa B. Żyłko. Gdańsk 2010.

Witkow ski W.: Między pedagogika, filozofia i kulturą. Studia, eseje, szkice. Warszawa 2007.

Życie to jednak strata jest. Andrzej Stasiuk w rozmowach z Dorota Wodecka. Warszawa 2015.

\section{Źródła internetowe}

https://archiwum.men.gov.pl/wp-content/uploads/2018/01/zalacznik-nr-1.pdf [data dostępu: 10.12.2018].

Rozporzadzenie MEN z dnia 27 sierpnia 2012 r. w sprawie podstawy programowej wychowania przedszkolnego oraz kształcenia ogólnego w poszczególnych typach szkót. https:// www.teraz matura.pl/docs/Podstawa-programowa-z-jezyka-polskiego-szkola-ponadgimnazjalna.pdf [data dostępu: 10.12.2018]. 